\title{
Reflections on the Politics of Immigration Problem in Assam: A Historical Perspective
}

\author{
Sanghamitra Sarma \\ Department of Political Science, Gauhati University, India
}

\begin{abstract}
The initial euphoria of independence from colonial rule in India soon subsided when Assam, one of the northeastern states of the country had to face a major challenge in the form of immigration into its territory. This was however not a post - colonial phenomenon. Immigration was a colonial policy designed to accomplish imperialistic designs of the British rulers. The paper explores the historical origins of the problem of immigration in colonial and post - colonial Assam and the politics that was being played within it which escalated the magnitude of the problem.

In the post-independence period, apathy of the central and state government, faulty laws and policies have led to burgeoning of the problem. Construction of illegal vote banks has enabled politicians without performance to keep returning to power. This has led to a sense of insecurity among the indigenous people of Assam whose socio - cultural identity remains threatened in the backdrop of unchecked immigration.
\end{abstract}

Keywords: Assam, demography, East Bengal, immigration, insecurity, identity.

\section{Introduction}

Independence of India in 1947 gave rise to many expectations among the people. In Assam too, people belonging to different communities had started to nurture new hopes, dreams and aspirations. But only very few of these dreams and aspirations saw the light of the day. The war and partition proved disastrous for Assam as she was bogged down by many problems and challenges. Food scarcity, natural disasters like perennial floods and the Great Earthquake of 1950, poverty and unemployment were only a few to name. But among these issues, the problem of immigration was a particularly serious one as it had its repercussions in the demography and politics of Assam even in the post - colonial period. This paper sets out to explore the historical origins of the problem of immigration in Assam and the politics that was being played within it which escalated the magnitude of the problem. The importance of policies taken in the colonial era to understand the conditions under which immigration was facilitated is sought to be deconstructed. The response of the governments in the post - colonial period have also been encompassed.

Assam is a strategically located state in the northeastern part of India. It is surrounded by six Indian states and two foreign countries. It has an area of 78, 550 square kilometers with a total population of 31 million making it the $14^{\text {th }}$ most populated state in India. It has a population density of 397 per square kilometer which is higher than the all - India population density of 382 per square kilometer [1]. To the west and southwest of Assam are two states which are predominantly Bengali. They are West Bengal (population 91 million) and Tripura (population 3 million) respectively [2]. Bangladesh (erstwhile East Bengal) with a population of 15 crores and population density of 1033.5 per square kilometer, also with Bengali - speaking majority, borders Assam. Thus Assam shares her borders with 24.4 crore of Bengali speaking population.

Immigration during the post - colonial period in Assam, did not capture the Indian popular imagination like the conflict in Kashmir and Punjab. Perhaps because of the fact that "Assam and the northeast are very far away; a 'sensitive border region' to use an Indian cliché; the image it evokes is of a borderland full of deviants conducting subversion" [3]. Two major factors that helped to keep the immigration issue out of the political agenda in the pre - 1979 period were firstly, the ethnic tensions arising from the language conflict which had occupied most of the space in the political discussions of that time and secondly the tacit agreement among political parties (including the Congress party) to come to a decision that immigration was a contentious issue and hence left safe if unattended to [4].

Undocumented and large scale immigration becomes problematic for any country to tackle as it causes drastic changes in the demographic balance of that country. But it raises higher and greater questions on political repercussions when immigration is dispensed by enfranchising 'refugees' and 'illegal immigrants' alike as was allegedly done by the Congress party of Assam until the 1970's [5]. Consequent to the partition of India in 1947, there occurred a huge movement of people into India from neighboring countries. Assam was one of the states of India to be affected by the process of immigration in a way that has challenged the demographic dimensions of the state as influx into this northeastern arm of the country did not cease even in the aftermath of the partition, as in Punjab. Hence it is imperative to delve into the historical origins of this problem. 


\section{Historical Origins of the Problem}

The First Anglo - Burmese Warii $(1824$ - 1826) between the British and the Burmese resulted in the victory of the East India Company in Assam. The state was incorporated into the Bengal Presidency in 1838. This territorial integration of Assam into colonial India opened the frontal gates for new settlements. With the introduction of Bengali as the official language, reorganization of Assam meant inducting many Bengalis in the administration department. Meanwhile, the repressive policies followed by the zamindars in East Bengal required the revolutionist elements to be exported to another area. Assam seemed to be a favorable option as quantity of cultivable lands here was much more as compared to the availability of land in East Bengal. At the same time the peasants of East Bengal flocked into Assam to carry out jute cultivation. The requirement of cheap labor to work in the tea industry encouraged many laborers from the Chotanagpur region to migrate to Assam as well. The discovery of coal and petroleum towards the later part of $19^{\text {th }}$ century opened the floodgates of immigration into Assam as streams of people started coming in mainly from Bengal, Bihar, Nepal and Rajasthan. This manpower was needed to run various departments, construct roads and railways, excavate the hidden coalmines and to work in various service sectors. Therefore the colonial government decided to boost the flow of immigrants to fulfill their imperialist goals.

The Bengali Muslims from Mymensingh and Rangpur of East Bengal in eager anticipation of settlement in Assam had started to grab lands at whatever price they could get. These Bengali Muslims cleared vast tracts of dense jungles along the south bank of the river Brahmaputra and occupied flooded lowlands all along it. Therefore to prevent indiscriminate settlement of immigrants, the government took certain measures. In 1916 according to the rules of land settlement, the government authorized the Deputy Commissioner to drive out immigrants who had not acquired appropriate right on a piece of land within three months of notice. The introduction of the Line System in 1920 which empowered the district officers to draw lines in order to restrict immigrants from occupying new lands, eliminated the developing tensions between the Assamese Hindus and the immigrant Muslims as the movements of the immigrants were restricted within definite tracts. Apart from the British rulers, the approach adopted as regards immigration by one of the foremost political leaders of modern Assam, Syed Mohammed Saadulla (Muslim League) should also be taken into account. A qualified parliamentarian, Saadulla was a great rationalist who was willing to assist the Britishers so as to usher constitutional reforms in the country. Saadulla's role becomes significant when we encounter with the fact that the land settlement policies followed by him, in violation with the Line System, gave indications to the Assamese elite that his Muslim League government in Assam was promoting the inflow of Muslims into the territory of Assam so that in due course of time it could be converted into a Muslim - majority province [6].

Saadulla's introduction of the land settlement policy opened up 1 lakh bighas iii of land in Assam Valley for the settlement of Bengali Muslim immigrants during 1939 - 1940 and proved very beneficial to these land hungry peasants who could hold as much as 30 bighas of land or more for each homestead [7]. Saadulla's government of 1942 further revised the regulations regarding grazing and forest reserves only to facilitate the incoming of more immigrants from East Bengal [8]. This second wave of immigration ${ }^{\text {iv }}$ to Assam created quite a stir in Gopinath Bardoloi's ${ }^{v}$ mind, who had been imprisoned in Jorhat jail since August, 1942 in connection with the Quit India Movement. The Line System was blatantly violated as streams of immigrants were permitted to enter and settle in the state. The flow of immigrants was so outrageously high that Saadulla at one point of time had to himself admit that Muslim immigrants had flooded the state [9]. But ironically he adhered to the policy of abandonment of the line system. It must be noted here that apart from the British and the Muslim League, Jawaharlal Nehru was also in favor of open borders. The reason cited was to implement the 'grow more food' campaign and meet the production demands. ${ }^{\mathrm{vi}}$ With the patronage of the British and political leaders, the population of Muslim immigrants saw a perceptible increase as revealed in the following table.

Table 1: Muslim Population of Assam from 1911 - 1941

\begin{tabular}{|c|c|}
\hline Year & Muslim Population \\
\hline 1911 & $3,55,320$ \\
\hline 1921 & $5,85,943$ \\
\hline 1931 & $9,43,352$ \\
\hline 1941 & $13,03,962$ \\
\hline
\end{tabular}

Source: Home Political Proceedings, File No. 169/46, National Archives of India, cited in A. C. Bhuyan and Sibopada De (Eds.). Political History of Assam 1940 - 47, 1980, Vol.3, pp. 262 [10].

The table shows that between the years 1911 to 1941, the Muslim population in the Assam Valley (including Garo Hills) had substantially increased. This increase in Muslim population resulted in the demand for the creation of a separate state for the Muslims. In 1940 the Lahore resolution of the All India Muslim League voted for a separate homeland for the Muslims of the country. Echoing this demand, Saadulla said, "The Pakistan Scheme demands that in order to avoid conflict between the Hindus and the Muslims they should live separately and establish separate states...If the Muslims be in majority in Assam then Assam and Bengal can 
form one Pakistan State and Punjab, North West Frontier Province and Sind can form another Pakistan State." [11]

The issue of immigration was discussed in the Assam Legislative Assembly, within and outside Congress from different perspectives. Sarveswar Barua (Congress) submitted a motion in the Assembly to highlight the troubles faced by indigenous people due to the land settlement policy of the government [12]. Bringing an Adjournment Motion in the Assembly on 16 November, 1944, another Congressman Beliram Das pointed out the forcible occupation of grazing reserves by immigrants from Bengal [13]. To this, Saadulla proposed to hold an All Party Conference where the earlier policies on land settlement would be revised. Though the Conference put forward certain proposals for consideration, however a mutually acceptable resolution on land settlement could not be arrived at as the revised policies were strongly opposed by Revenue Minister Munawwar Ali and Finance Minister Abdul Matin Choudhury, both belonging to the Muslim League.

The Muslim members of Saadulla's ministry differed from their Congress counterparts regarding immigration. For instance, in 1945 responding to Maulavi Matior Rahman Mia's enquiry about the presence of number of settled immigrants in Assam, Maulavi Munawwar Ali informed that their number could not be ascertained. Several Muslim Leaguers like Maulavi Matior Rahman Mia wanted that the government should open up vast tracts of wastelands for settlement of immigrants [14]. Munawwar Ali interestingly wanted to keep on postponing the discussion regarding the Adjournment Motion on immigration raised by Beliram Das [15]. However on the persistence of the then Speaker, Babu Basanta Kumar Das, the motion was aptly raised and a lively discussion took place in the Assembly. In this way, though the rays of legislative politics fell on the question of immigration, yet nothing concrete could be done to restrain it in the colonial period. In fact, as it is obvious from the above description, Muslim population of the state went on increasing, culminating to the demand for inclusion of Assam with East Pakistan. Meanwhile land for the immigrants was being settled in accordance with the policy laid down by the government.

\subsection{Cabinet Mission Plan and Assam:}

The Cabinet Mission's $\mathrm{s}^{\text {vii }}$ proposals to carve a confederation of two groups of provinces which would be formed on the basis of religion, i.e., Hindus and Muslims, was met with deep resentment by the Assamese public opinion.

When the recommendations of the Plan were announced, it gave rise to panic among the people of Assam. One of the clauses envisaged the division of provinces of India into sections A, B and C. Assam according to Section $\mathrm{C}$ was to be grouped along with Bengal and become a Muslim majority province. This violated the basic principle of provincial autonomy because of which Assam and particularly the Assam Pradesh Congress Committee (APCC) (the state level Congress Committee) reacted immediately. The Working Committee of the APCC sent a telegraph to the then Congress President Abul Kalam Azad on 16 May, 1946 communicating their decision of opposing the grouping clause of the Cabinet Mission. A five member Committee was formed to organize an anti - grouping movement in the province. It was decided that 5 June would be observed as the 'anti - grouping day'. The APCC rose to the occasion and made an appeal to the various organizations, students and youths to sensitize and mobilize public opinion on the issue of grouping. Bardoloi also wanted the Congress volunteers to prepare themselves for a mass movement in the wake of the Congress Working Committee's session on 10 June in which Bardoloi feared that the recommendations of the Cabinet Mission would be accepted in its entirety, which would mean that Assam would be grouped with East Bengal. Bardoloi was thus ready to go against his own party to save Assam's future. The APCC also shared similar concerns with Bardoloi.

The response to Bardoloi's call was felt in different directions. The Assam Jatiya Mahasabha ${ }^{\text {vii }}$ fully supported Bardoloi and its General Secretary, Ambikagiri Rai Choudhury announced that he would go on a fast unto death strike to save Assam from being grouped. The All Assam Students Union ${ }^{\text {ix }}$ (AASU) and the Communist Party of India in Assam also lodged their respective reservations against the Cabinet Mission. The Muslims of Assam had different opinions on the issue. The Muslim League and the Muslims of the Surma Valley ${ }^{\mathrm{x}}$ favored the grouping. Saadulla held the view that Assam was dependent on Bengal for economic purposes and grouping would help in administration of Assam. According to him, the Cabinet Mission had shown 'great statesmanship' in grouping Assam with Bengal [16]. On the other hand, the Assamese Muslims were confused regarding acceptance of the proposals of the Cabinet Mission. On one hand they wanted to preserve their Assamese ties with the greater Assamese population but on the other hand accepting the grouping clauses would imply increase in the numerical strength of the Muslim community.

Throughout Assam 5 June was observed as the 'anti - grouping day'. Meetings and processions were carried out in towns across Kamrup, Nowgong, Jorhat, Darrang, Goalpara and North Lakhimpur districts. Lawyers, students, women and youths came out in support of APCC's call for opposition to the Cabinet Mission's grouping plan. 
As noted earlier, the Muslim League welcomed the formation of groups. Mohammed Ali Jinnah justified the grouping on the ground of availability of the provision of opting out of it, if the identity of the province was threatened. But Bardoloi steadfastly opposed the proposed grouping of Assam and was not ready for any compromise. On the other hand, the All India Congress Committee ${ }^{\mathrm{xi}}$ (AICC) had accepted the Cabinet Mission Plan on 10 August, 1946 and had planned to proceed with the Constituent Assembly. The national Congress particularly Nehru and Azad, dismissed off Assam's concerns expressed by Bardoloi as 'unjustified' [17].

As per the decision of the APCC, Gopinath Bardoloi submitted a Memorandum to the Congress Working Committee on December 9, 1946 expressing firm determination to reject the Grouping clause. He wrote,

"If Her Majesty's Government's proposals are to be accepted both our constitution as well as Grouping will be determined by the majority of the Constituent Assembly Members sitting in Group ' $\mathrm{C}$ ', with the inevitable result that we shall be thrown entirely at the mercy of the Muslim League both for our provincial constitution as well as our Grouping. With this perspective of a Section before us, we, the members of the Constituent Assembly from Assam, can have but only one decision; and, that is that we refuse to go to that section." [18]

In this regard it must be mentioned that the Working Committee of the National Congress had offered little help to the Congressmen of Assam on the course of action to be adopted. Instead, Nehru and Azad persuaded the Assam delegation to shed off their fears about the grouping. However, Mahatma Gandhi was much more supportive than the National Congress in understanding the concerns of the people. Therefore the APCC sent two Congress workers namely, Bijoy Chandra Bhagabati and Mohendra Mohan Choudhury to meet him on 15 December, 1946 to acquire advice on this matter. Gandhiji clearly remarked,

"I do not need a single minute to come to a decision for on this I have a mind....if there is no clear guidance from the Congress Working Committee Assam should not go into the sections. It should lodge its protest and retire from the Constituent Assembly. It will be a kind of Satyagraha against the Congress for the good of the Congress....If Assam keeps quiet it is finished. No one can force Assam to do what it does not want to do." [19]

Gandhiji's encouragement to the Assam Congress leaders helped them to frame their mind regarding the stand to be adopted on the Cabinet Mission Plan. Bardoloi thereby informed Nehru that Assam would firmly go by Gandhiji's advice and frame her own Constitution. The AICC at a plenary session in January 1947 reviewed the situation for the people of Assam in the wake of similar reservations expressed by the Sikhs. In a resolution adopted on 6 January, 1947, the AICC stated that the provinces of the country should be vested with the power of deciding their own fate, should they be compelled to join another province which might endanger their autonomy and rights. But this resolution could assuage the fears of neither the non - Muslim Assamese nor the APCC. The latter consistently reiterated its stand of framing the province's Constitution only by its own representatives. In the face of Assam's unswerving opposition to the Cabinet Mission's Grouping Plan, the recommendations of the Plan could not be materialized and it remained, for all its purposes, null and void. Lord Wavell was replaced as the Viceroy of India and in his place Mountbatten was appointed. Mountbatten was convinced that the Cabinet Mission was unsuitable for the country in the changed circumstances. Therefore, partition of the country on communal basis was inevitable.

\subsection{Partition and Transfer of Sylhet}

Lord Louis Mountbatten as the last Viceroy of British India was entrusted with the responsibility of making an arrangement for transfer of power. He constructed a Plan wherein the country would be divided on a communal basis. As it came to be known, the Mountbatten Plan of 3 June, 1947 envisaged partition of India and formation of a new Constituent Assembly. Regarding Assam, the Mountbatten Plan recognized the demand for inclusion of Sylhet district within East Bengal and announced that a referendum would be the deciding factor for ascertaining the geographical future of Sylhet. The Sylhet referendum resulted in the transfer of majority portion of Sylhet with East Pakistan whereas the three thanas of Patharkandi, Ratabari and Badarpur and about one half of the thana of Karimganj remained in Assam.

\section{Politics of Immigration in Post - Colonial Period}

In the post - colonial period, the Assamese emerged as the dominant section of the society asserting their power in the government. The Bengali Muslims of East Bengali origin residing in Assam started to feel insecure amidst the growing dominance of the Assamese. They were already apprehending expulsion from India in the wake of the passage of the Immigrants Expulsion (from Assam) Act in 1950 xii. In the changed circumstances the Bengali Muslims decided to appease the Assamese people by declaring their mother tongue as Assamese and by endorsing the pro - Assamese government on the official language issue for the state. This covert pact of understanding went on for some time. Problems started to crop up after the creation of 
Bangladesh. The 1971 Indo - Bangladesh war was followed by another major influx from Bangladesh to Assam. Around 10 million people crossed over to Indian borders due to fear of religious persecution and political pressure. Many of these people stayed back and mixed with the mainstream of Assamese socio cultural life. In 1971, the census reported an increase of 820,000 Muslims or approximately 424,000 more than could be accounted for by natural population increase in Assam [20]. According to government estimates, the population of Assam increased from 14.6 million in 1971 to 19.9 million in 1981[21]. ${ }^{\text {xii }}$ Bangladesh refused to take responsibility for the immigrants who had entered illegally before $25 \mathrm{March}, 1971$, i.e., before the birth of Bangladesh. In 1979, shortly before the parliamentary election, the Chief Election Commissioner, S. L. Shakdher stated that the electoral rolls for Assam had been inflated by the inclusion of illegal Bengali migrants from Bangladesh. This news sent waves of panic across the entire Brahmaputra Valley. It was hence apparent that the conscious Assamese people opposed the 1979 parliamentary elections. The AASU came forward demanding that the electoral rolls be prepared again to eliminate those who had entered India illegally. A civil disobedience movement was soon called as no agreement could be reached regarding the revision of electoral rolls. Thus with the launch of the Assam Movement, the first organized resistance for expulsion of immigrants took place, with the movement turning violent in places like Nellie (near Nowgong district), Chaulkhowachapori (Darrang district) and Silapathar (Lakhimpur district). A six year long agitation came to an end with the signing of the Assam Accord between the Government of India and the leaders of the movement in New Delhi on 15 August 1985. The Accord paved the way for the leaders of the agitation to form a political party, namely the Assam Gana Parishad (AGP) which came to power in 1985. However the party failed to implement the provisions of the Assam Accord in both of its tenures (24 December 1985 - 28 November 1990 and 15 May 1996 - 17 May 2001). "The growth of population in Assam during 1951 - 2001 was 136.38 per cent against the national growth rate of 116.30 per cent" [22]. The inordinate delay in implementing the core issues of the Accord, like detection of illegal foreigners, fencing the India - Bangladesh border and scrapping the controversial Illegal Migrants (Determination by Tribunal) Act, $1983^{\text {xiv }}$ (which was actually the biggest deterrent in the identification and deportation of illegal immigrants) led to loss of trust in the AGP government by the people of Assam which was ultimately thrown out of power from the state politics.

During the years of Congress government's rule too, the issue of immigration has not been addressed sincerely. The Congress party which had so intensely opposed the Cabinet Mission's Grouping Plan to include Assam in the Muslim - majority province of East Bengal changed its policy towards immigrants and began to utilize them as vote banks for securing political advantages in elections. As a result immigration has only increased day by day. The presence of illegal immigrants in Assam was explicitly pronounced in a July 2008 verdict of the Gauhati High Court. In a case involving 61 people who were detected 'foreigners', the court said that most of them were able to avoid their deportation from India and that they had incorporated their names in the voters' lists on the basis of which they had cast their votes. The court also noted that 'large number of Bangladeshis' in the state played a major role in electing representatives both to the Legislative Assembly and Parliament and consequently, in the decision - making process of the country. There are also more than 38,000 declared foreigners from Bangladesh in the state who are yet to be deported. Many of those who were detected even disappeared mysteriously and are now 'traceless' [23]. Porous borders and apathy of the Central and state governments to implement the main clauses of the Accord have resulted in inaction regarding detection and deportation of illegal immigrants. The process of updating the National Register of Citizens (NRC) which could have helped in the detection of illegal immigrant settlers in Assam has not seen the light of the day and remains a mere farce.

\section{Conclusion}

The Human Development Report, 2009 titled 'Overcoming Barriers: Human Mobility and Development' states, "Large gains to human development can be achieved by lowering the barriers to movement and improving the treatment of movers" [24]. Western nations owe a major part of their existence to migration. They have indulged in celebratory acts of welcoming migrants resulting in expansion of culture. However such celebration cannot be performed in a state like Assam where questions of immigration have started to cast shadows of concern on the realm of identity [25].

The initial benefits of immigration have been replaced by a fear of outsiders threatening the socio cultural and economic identities of the indigenous people and simultaneously also causing shifts in the demographic balance. Today immigration problem has virtually burgeoned into a curse. Lack of political will of the ruling parties in Assam to come to a mutually agreeable solution on the vexed issue has worsened the situation. It may be noted here that after a long hiatus the issue of illegal infiltration from Bangladesh has been revived on the Centre's agenda. "Both the UPA - I and UPA - II governments maintained a stoic silence over the controversial issue. The Manmohan Singh Government initially acknowledging existence of illegal migrants, in the Rajya Sabha, later retracted the statement" [26]. The hope now lies in what policies the 
Narendra Modi - led government adopts to expel the illegal immigrants from Assam. In this context strong public opinion will be helpful to put pressure on the current NDA government.

\section{Acknowledgement}

The financial assistance in the form of a Doctoral Fellowship from Indian Council of Social Science Research (ICSSR), New Delhi, India received by the author is gratefully acknowledged. The author is also grateful to Dr. Sandhya Goswami, Professor, Department of Political Science, Gauhati University, Assam for giving her valuable comments and guidance in the preparation of this paper.

\section{References}

[1]. Census 2011 - Assam, [Online] Available: http://online.assam.gov.in/web/population-census (November 10, 2014).

[2]. States Census 2011, [Online] Available: http://www.census2011.co.in/states.php (November 10, 2014).

[3]. Interview with Sanjib Baruah, Conducted by Nermeen Sheikh, Asia Society (n.d., para 11) [Online] Available: http://asiasociety.org/policy/interview-sanjib-baruah (April 26, 2013).

[4]. Sanjib Baruah, Immigration, Ethnic Conflict and Political Turmoil - Assam, 1979 - 1985, Asian Survey, 26(11), 1986, 1184 1206.

[5]. Sanjib Baruah, Assam: Confronting a Failed Partition (November 2008, para 7) [Online] Available: http://www.indiaseminar.com/2008/591/591 sanjib baruah.htm (September 27, 2013).

[6]. Girin Phukon, Assam: Attitude to Federalism (New Delhi: Sterling Publishers, 1984) 13 -15.

[7]. Land Revenue Administration Report of Assam, 1939 - 1940, Government of Assam, Shillong, Appendix IV, p. 23 cited in Girin Phukon, Assam: Attitude to Federalism (New Delhi: Sterling Publishers, 1984) 14.

[8]. Ibid, p. 16 .

[9]. Amalendu Guha, Planter raj to swaraj: Freedom struggle and electoral politics in Assam 1826-1947 (New Delhi: People's Publishing House, 1977) $282-283$.

[10]. A.C Bhuyan and Sibopada De (Eds.), Political history of Assam Vol. 3. (Gauhati: Department for the preparation of the political history of Assam, 1980) 262.

[11]. B.J. Dev and D.K. Lahiri, Assam Muslim politics and cohesion (Delhi: Mittal Publications, 1985) 71.

[12]. Assam Legislative Assembly Debates (ALAD), 13 November, 1944, 2(11), 807.

[13]. ALAD, 16 November, 1944, 2(13), 908 - 914.

[14]. ALAD, 12 March, 1945, 1(6), 345- 46.

[15]. ALAD, 13 November, 1944, 2(11), 803 - 807.

[16]. Political Situation Reports, Home Political Proceedings, File No. 51/2/1946, National Archives Of India (NAI), New Delhi cited in A. C Bhuyan and Sibopada De (Eds.), Political history of Assam 1940 - 47, Vol.3 (Gauhati: Department for the preparation of the political history of Assam, 1980) 354 .

[17]. Abul Kalam Azad, India wins freedom: An autobiographical narrative (Calcutta: Orient Longmans, 1959$) 201$ - 202.

[18]. Publicity Department of the Assam Pradesh Congress Committee, A Note on Assam's Stand vis-à-vis British Government Statement of 6 December (Gauhati: New Press, 1946) Gopinath Bardoloi Papers, List No. 170, File No.5, Nehru Memorial Museum and Library (NMML), New Delhi, 11.

[19]. Publicity Department of the Assam Pradesh Congress Committee, A Note on Assam's Stand vis-à-vis British Government Statement of 6 December (Gauhati: New Press, 1946) Gopinath Bardoloi Papers, List No. 170, File No.5, Nehru Memorial Museum and Library (NMML), New Delhi, $14-15$.

[20]. Myron Weiner, The Political Demography of Assam's Anti - Immigrant Movement, Population Development Review, 9(2), 1983, 279 - 292 [Online] Available: http://www.jstor.org/stable/1973053 (September 28, 2012).

[21]. Pravin Visaria \& Leela Visaria, India's population: Second and growing. Population Bulletin, 36(4), 1981, 10 - 13, cited in Myron Weiner, The Political Demography of Assam's Anti - Immigrant Movement, Population Development Review, 9(2), 1983, 279 292 [Online] Available: http://www.jstor.org/stable/1973053 (September 28, 2012).

[22]. M Amarjeet Singh, A Study on Illegal Immigration into North - East India: The Case of Nagaland, IDSA Occasional Paper (8), 2009, New Delhi: Institute for Defense Studies and Analyses, 15, [Online] Available: http://www.google.co.in/url? sa=t\&rct=i\&q=\&esrc=s\&source=web\&cd=2\&ved=0CCEQFjAB\&url=http $\% 3 \mathrm{~A} \% 2 \mathrm{~F} \% 2 \mathrm{Fwww} . \mathrm{idsa}$. in \%2Fsystem $\% 2$ Ffiles\%2FOccasionalPaper8 NagalandIllegalImmigrationl.pdf\&ei=LJ5hVLzCIMWxuASqvILgCw\&usg=AFQjCNE objpKycjaAukaTH1t81W0TcRORA\&sig2=xIk7n4wtUMuyM-kV4TccAA (November 11, 2014).

[23]. 38,000 declared Bangla immigrants roaming freely in Assam (2012, 7 April) The Times of India [Guwahati] Retrieved August 22, 2014 from http://timesofindia.indiatimes.com/city/guwahati/38000-declared-Bangla-immigrants-roaming-freely-inAssam/articleshow/12574121.cms

[24]. Human Development Report 2009 [Online] Available: http://hdr.undp.org/en/media/HDR 2009 EN Complete.pdf (September 29, 2013) 7.

[25]. Nandana Dutta, Questions of identity in Assam: Location, Migration and Hybridity (New Delhi: Sage Publications, 2012).

[26]. Influx problem in NE to get priority (2014, June 10) The Assam Tribune [Guwahati] 1.

\section{Notes}

${ }^{\mathrm{i}}$ On the evening of $15^{\text {th }}$ August, 1950 an earthquake measuring 8.6 in the Richter scale had struck the state letting loose a chain of devastation of lives and property. The energy of this shock was felt over an area of 1.75 million square miles. This great earthquake brought about destruction over large tracts of Upper Assam and in the hills of the North - East Frontier Agency.

${ }^{i i}$ For six hundred years Assam was ruled by the Ahoms, a Shan Tribe. Internal dissensions gradually weakened the Ahom central administration. Badan Chandra Barphukan, Chief of Ahom forces connived with the Burmese asking support to invade Assam and defeat his political rival, Purnananda Burhagohain, the Prime Minister of the Ahom kingdom. The British authorities meanwhile grew increasingly insecure about the presence of the 
Burmese so near to Calcutta, which was already under their (British) control. So in order to confront the Burmese, the British interfered and thus the first Anglo - Burmese War took place in 1826. It resulted in the fall of the Ahom kingdom and British annexation of Assam.

iii Bigha is a traditional unit of land used in several parts of India. It is usually less than an acre (0.4 hectare), however it can extend up to 3 acres. Various states have different sizes ascribed to 1 Bigha.

${ }^{\text {iv }}$ The first wave was the labor force imported from tribal regions of Bihar to work in the fields and the third and fourth waves were Bengali Muslims from East Bengal. These are known as the four waves of migration to Assam.

v Gopinath Bardoloi was the first Chief Minister of Assam in independent India. He was an eminent Congressman, a freedom fighter and a strict Gandhian. He opposed the Cabinet Mission's recommendations and played a pivotal role in saving Assam from being 'grouped' with East Bengal. He was also instrumental in establishing the Gauhati University and the High Court of Assam, Assam Medical College and Assam Veterinary College.

${ }^{\mathrm{vi}}$ In the period following independence, most parts of India were facing food shortage problem due to rise in population, devastating Bengal famine in 1943 which affected the supply of food grains in the whole of India, and because of hoarding and black marketing of food supplies. To raise food supplies, increase production of food and check inflation, the Grow More Food Campaign was introduced by the colonial government in 1942. Nehru was of the view that the refugees and immigrant population in Assam would help the cultivators in growing more food, thus contributing to Assam's economy.

vii The Cabinet Mission comprising of Lord Pethick Lawrence, Secretary of State for India, Stafford Cripps, the President of the Board of Trade and A.V. Alexander, the first Lord of Admirality arrived in India on 23 March, 1946.

viii The Assam Samrikshini Sabha founded in 1926 by Ambikagiri Rai Choudhury was established for preserving the interests and identity of the Assamese people. It was later rechristened as the Assam Jatiya Mahasabha.

${ }^{\text {ix }}$ In 1940, a student union named Asom Chattra Sanmilani (Assam Students' Association) divided into the All Assam Student' Federation and the All Assam Students' Congress. A decade later they recombined as the All Assam Student' Association, which was later renamed to All Assam Students Union in January 1967.

${ }^{\mathrm{x}}$ Located south of Eastern Himalayas, Assam comprises of the Brahmaputra and the Barak River Valleys. Barak Valley was an extension of the greater Surma Valley (now partly in Bangladesh).

${ }^{x i}$ All India Congress Committee (AICC) is the central - decision making body of the Indian National Congress.

xii The Act had the power to order expulsion of certain immigrants who were considered to be detrimental to the interests of the general public by the Central Government. The Act implicitly distinguished between Hindu refugees and illegal immigrants. It was repealed later due to political compulsions.

xiii Since the census was not conducted in 1981 due to communal disturbances, these figures are estimates.

${ }^{x i v}$ Under the Foreigners Act, 1946, the onus of proving the citizenship status was on the person concerned. The IMDT Act, 1983 stated that a person making a complaint must be a resident within the jurisdiction of the same police station as the person in relation to whom the application is made. The law also provided that a complaint could be rejected if it was found to be frivolous. Thus tacitly the law provided undue protection to the person whose citizenship was questioned. Later the Supreme Court repealed this Act in 2005. 